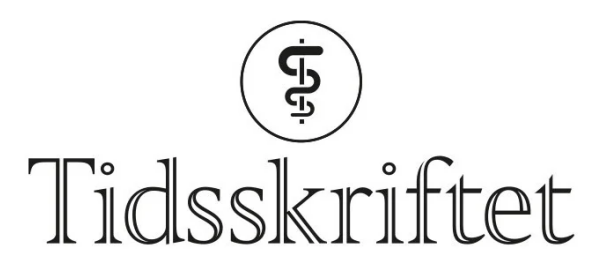

DEN NORSKE LEGEFORENING

\title{
Pandemiberedskap på en fødeavdeling
}

DEBATT

\section{JOHAN KIPPERVIK}

johan.kippervik@stolav.no

Johan Kippervik er overlege ved Seksjon for gynekologisk kreft, St. Olavs hospital og Leder av Kvinneklinikkens beredskapsutvalg.

Forfatteren har fylt ut ICMJE-skjemaet og oppgir ingen interessekonflikter.

\section{TONE SELMER-OLSEN}

Tone Selmer-Olsen er fagutviklingsjordmor ved Fødeavdelingen, St. Olavs hospital.

Forfatteren har fylt ut ICMJE-skjemaet og oppgir ingen interessekonflikter.

\section{ELISABETH B. MAGNUSSEN}

Elisabeth B. Magnussen er ph.d. og seksjonsoverlege ved Fødeavdelingen, St. Olavs hospital. Forfatteren har fylt ut ICMJE-skjemaet og oppgir ingen interessekonflikter.

\section{TONE SHETELIG LØVVIK}

Tone Shetelig Løvvik er ph.d. og overlege ved Fødeavdelingen, St. Olavs hospital. Forfatteren har fylt ut ICMJE-skjemaet og oppgir ingen interessekonflikter.

\section{Koronasmitte på en fødeavdeling kan få store konsekvenser både driftsmessig og rent medisinsk. En kvinne med kjent koronasmitte fødte nylig ved vår avdeling, og vi håper våre erfaringer og forberedelser kan være til hjelp for andre avdelingers pandemiberedskap.}

Koronapandemien gir uvante utfordringer i alle ledd av helsetjenesten. Norske fødeavdelinger forventes ikke å bli hardest rammet, men har mange døgnopphold i forbindelse med fødsel, og ikke-planlagte polikliniske konsultasjoner i ukene før fødsel. Mange fødeavdelinger er arealmessig små og har varierende isolasjonsfasiliteter. Tilgangen på jordmødre er begrenset, både ved små og store avdelinger, og jordmødre kan ikke erstattes av tilfeldige sykepleiere fra andre avdelinger. 
På bakgrunn av de omfattende smittevern- og karantenebestemmelsene har scenarioet med koronasmitte på en slik avdeling store potensielle konsekvenser. Fødeavdelingen ved St. Olavs hospital er en del av Kvinneklinikken og en av landets større fødeavdelinger, med omkring 3700 fødsler årlig. Avdelingen ivaretar lokal- og regionsykehusfunksjoner for fødselshjelp. Som sykehusets øvrige avdelinger har også Fødeavdelingen de siste ukene jobbet med å forberede eventuelt mottak av koronasmittede pasienter. Vi har testet flere pasienter, men foreløpig har ingen fått påvist koronasmitte.

\section{En høygravid kvinne med kjent koronasmitte}

En kommunal smittevernoverlege kontaktet nylig fødeavdelingens koordinerende jordmor om at de hadde diagnostisert en gravid kvinne i 3o-årene med sars-CoV-2 og symptomer på covid-19 (1). Hun var gravid i uke 37, hadde et mildt til moderat sykdomsforløp og var under hjemmebehandling.

Kvinnen var tredjegangsfødende med et normalt forløpende svangerskap, men med en tidligere komplisert obstetrisk historie bak seg. Første fødsel ble utført med keisersnitt grunnet protrahert fødselsforløp og begynnende korioamnionitt, og andre fødsel med vakuumekstraksjon pga. protrahert forløp. Begge fødslene startet spontant i svangerskapsuke 38-39 og det ble forløst spreke barn. Ut ifra tidligere sykehistorie kunne vi forvente at kvinnen kom i fødsel i nær framtid.

Før mottak av denne kvinnen hadde vi ferdigstilt første versjon av lokal beredskapsplan for Kvinneklinikken, med nødvendige retningslinjer for mottak/behandling av én eller flere koronasmittede pasienter. Ved oppstart av dette arbeidet var isolasjon etter luftsmitteregime anbefalt. Underveis endret dette seg til dråpesmitteisolering (므).

Fødeavdelingen har to godkjente luftsmitteisolater, med nødvendig sluse, bad/WC og dekontaminator. Det ene isolatet er en fullverdig fødestue og det andre ligger i barselseksjonen (figur 1). Skulle vi motta flere koronapositive kvinner samtidig, tilsier vårt nye planverk kohortisolasjon av de (mistenkt) positive kvinnene. 


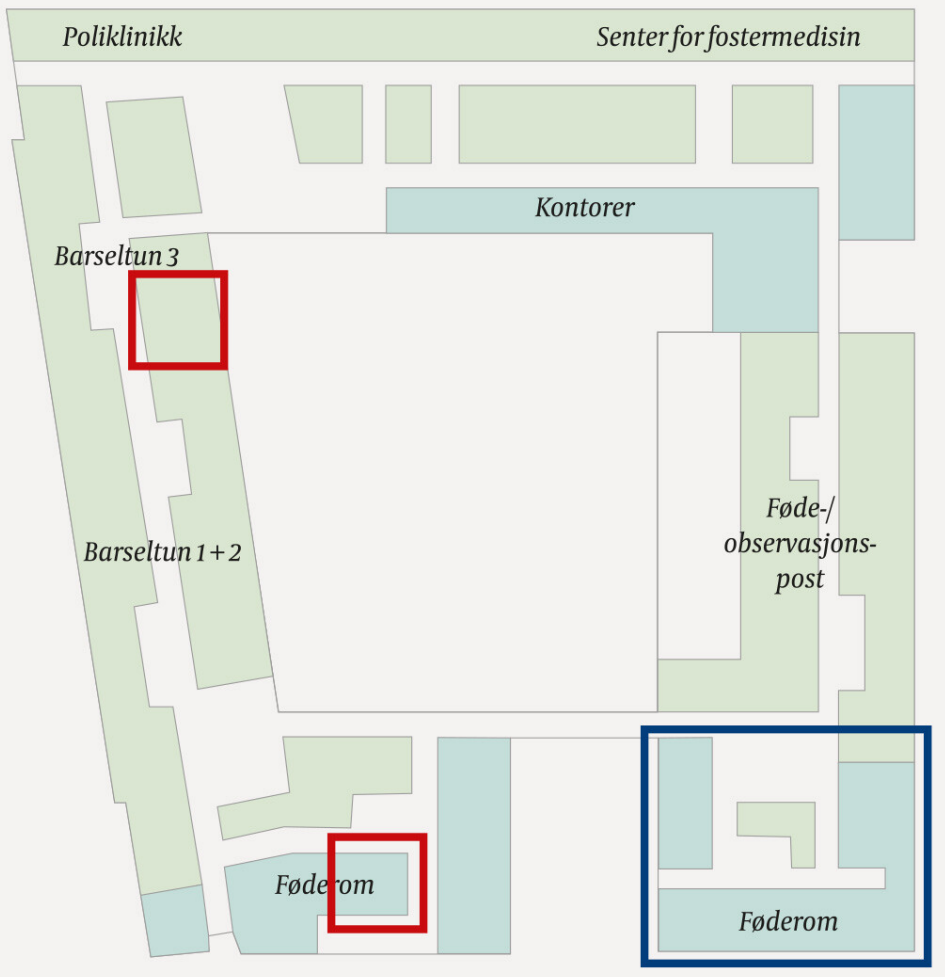

Figur 1 Etasjeskisse for observasjonspost, føde- og barselavdelinger og Senter for fostermedisin. Røde kvadrater er luftsmitteisolater. Blått rektangel er planlagt område for kohortisolasjon.

Ettersom vi forventet at den aktuelle kvinnens fødsel var nært forestående, og med tanke på hennes forhistorie, gjennomførte vi en fullskala «scenariotrening» med tilkalling av gynekolog og barnelege og et fødselsforløp som utviklet seg slik at overflytting til operasjonsavdelingen (tre etasjer under føden) for umiddelbar keisersnittforløsning i narkose (katastrofekeisersnitt) ble nødvendig. Varsling av involvert personell (nyfødtintensivavdeling, anestesi og operasjonsavdeling) gjøres via lokal AMK-sentral som sender ut melding via egen samtalegruppe på nødnettsambandet.

«Ettersom vi forventet at den aktuelle kvinnens fødsel var ncert forestående, gjennomførte vi en fullskala 'scenariotrening'»

I tiden fra smitten ble kjent til fødsel var lege og jordmor flere ganger i telefonisk kontakt med den gravide. Med bakgrunn i hennes tidligere fødsler ble forløsningsmåte drøftet: elektivt keisersnitt eller vanlig vaginal fødsel. Etter samtale med kvinnen valgte vi etter hennes ønske å planlegge vaginal fødsel, noe som er i henhold til nylig publiserte retningslinjer fra Norsk gynekologisk forening (3). Dette vurderte vi også som fornuftig smittevernmessig, for ikke unødig å utsette flere yrkesgrupper for smitterisiko.

Kvinnen kom inn i svangerskapsuke 38+6 med spontan fødselsstart, vel en uke etter påvist koronasmitte. Allmenntilstanden var god, hun hadde ikke feber, men sparsom tørrhoste. 
Som beskrevet i våre planer ble hun møtt av jordmor ved klinikkens ambulanseinngang. Der ble hun iført kirurgisk munnbind og fulgt direkte til isolatfødestuen, hvor hun var frem til barnet var født. Fødselen forløp ukomplisert, og barnet ble født midt i et vaktskifte.

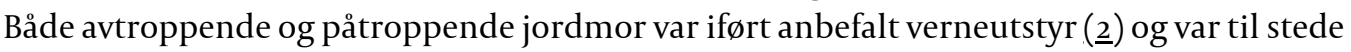
da barnet ble født. Barnet var sprekt og ble værende hos mor, etter anbefaling fra det nasjonale nyfødtmedisinske miljøet (4.). Hun ble utskrevet fjerde dag etter fødselen, etter et ukomplisert barselforløp.

\section{Beredskap og scenariotrening}

Etter lov om helsemessig og sosial beredskap (5) er kommuner, fylkeskommuner, regionale helseforetak og staten pliktige til å utarbeide beredskapsplaner for kriser og katastrofer. I helsevesenet er det ulik kultur for å opprette, vedlikeholde og trene etter slike planer. I en travel hverdag er det ofte vanskelig å finne rom for å prioritere dette. I tillegg er det utfordrende å formidle eksisterende planer. E-postboksen fylles fort, og nok en e-post om nok en endret prosedyre kan fort drukne mellom alt annet.

Under den pågående og hittil uforutsigbare koronapandemien har myndighetene åpnet opp for reduksjon i planlagt aktivitet. I tillegg til å redusere smittepresset bidrar dette til at vi har kunnet sette av personell til å jobbe målrettet med pandemiplanlegging.

I vårt helseforetak har avdelinger i ulik grad endret sine bemanningsplaner. Vår egen klinikk deler f.eks. opp legegruppen for å ha noen i beredskap dersom mange må i karantene eller blir syke. Dette er utfordrende og i varierende grad mulig for de forskjellige personellgrupper, avdelinger, klinikker og sykehus. Jordmødre er, som intensivsykepleiere, en begrenset ressurs som ikke kan erstattes fra et sykehusinternt bemanningssenter.

Smittepasienter er ikke uvanlig i fødeavdelinger, men koronaepidemiens omfang og mange ukjente faktorer nødvendiggjorde oppdatering av eksisterende rutiner og retningslinjer - og utforming av nye.

Vi har nå testet noen av disse både ved scenariotrening og med den første koronasmittede pasienten, som tross risikoanamnese fødte normalt. Det vil vise seg hvordan de nye planene står seg ved større pågang av koronasmittede gravide. Vi vil anbefale alle kollegaer å forberede seg grundig, ut fra de forutsetninger man har både infrastruktur- og personellmessig på det enkelte sykehus.

Vi har i våre pandemiforberedelser merket at råd og anbefalinger endres nesten daglig. Ikke minst ser vi at de rådgivende organer oppdaterer og omstrukturerer sine nettsteder flere ganger ukentlig. Illustrerende nok ble egen fagmedisinsk forenings første veiledning (3) oppdatert (ㅁ) i løpet av det døgnet denne kasuistikken ble til.

Pasienten har gitt samtykke til at artikkelen blir publisert.

\footnotetext{
LITTERATUR

1. Coronaviridae Study Group of the International Committee on Taxonomy of Viruses. The species Severe acute respiratory syndrome-related coronavirus: classifying 2019-nCoV and naming it SARSCoV-2. Nat Microbiol 2020; 5: 536-44. [PubMed][CrossRef]

2. Norsk folkehelseinstitutt. Personlig beskyttelsesutstyr ved covid-19, inkludert råd om utvidet bruk og gjenbruk. https://www.fhi.no/nettpub/coronavirus/helsepersonell/personlig-beskyttelsesutstyr/ Lest 11.3.2020.

3. Jacobsen AF, Findal G, Sitras V et al. Råd for håndtering av gravide med påvist/mulig CoVid19infeksjon (koronavirus). Norsk gynekologisk forening. https://www.legeforeningen.no/foreningsledd/fagmed/norsk-gynekologiskforening/veiledere/svangerskap-covid19/ Lest 16.3.2020.
} 
4. Norsk barnelegeforening. Informasjon, veiledere og prosedyrer for barn og Covid-19. https://www.legeforeningen.no/foreningsledd/fagmed/norsk-

barnelegeforening/veiledere/informasjon-veiledere-og-prosedyrer-for-barn-og-covid-19/ Lest 13.3.2020.

5. LOV-200o-06-23-56. Lov om helsemessig og sosial beredskap (helseberedskapsloven). https://lovdata.no/dokument/NL/lov/200o-o6-23-56 Lest 26.3.2020.

6. Findal G, Greve-Isdahl M, Sitras V et al. Koronavirus ved svangerskap og fødsel. Norsk gynekologisk forening. https://www.legeforeningen.no/foreningsledd/fagmed/norsk-gynekologisk-

forening/veiledere/koronavirus-ved-svangerskap-og-fodsel/ Lest 27.3.2020.

Publisert: 3. april 2020. Tidsskr Nor Legeforen. DOI: 10.4045/tidsskr.20.0270

Mottatt 27.3.2020, godkjent 1.4.2020.

(C) Tidsskrift for Den norske legeforening 2023. Lastet ned fra tidsskriftet.no 26. april 2023. 